\title{
FIRST REPORT OF MICROCYSTINS IN TAIWAN
}

\author{
TZONG-HUEI LEE, ${ }^{1}$ YIH-MIN $\mathrm{CHEN}^{2}$ and HONG-NONG $\mathrm{CHOU}^{2 *}$ \\ ${ }^{1}$ Department of Zoology, National Taiwan University, Taipei, 10617, Taiwan R.O.C.; and \\ ${ }^{2}$ Institute of Fisheries Science, National Taiwan University, Taipei, 10617, Taiwan R.O.C.
}

(Received 3 June 1997; accepted 13 September 1997)

Tzong-Huei Lee, Yih-Min Chen and Hong-Nong Chou. First report of microcystins in Taiwan. Toxicon 36, 247-255, 1998.-This is the first report on microcystins from Microcystis aeruginosa Kützing in Taiwan. A total of nine strains of cyanobacteria have been isolated from eutrophic aquaculture ponds and water reservoirs. By mouse toxicity assay, six of the nine strains had $\mathrm{LD}_{100}$ in the range of $25-100 \mathrm{mg}$ per $\mathrm{kg}$ mouse for dried bacterial mass. Microcystin-LR and -RR were found in all toxic strains and their contents ranged from $0.11-10.06 \mu \mathrm{g}$ and $0.08-2.21 \mu \mathrm{g}$ per $\mathrm{mg}$ of dried bacteria, respectively. Microcystin-RA, a minor component found only in $M$. TN-2 and $M$. CY-1 strains, was identified as a new microcystin. All three toxins were isolated by a serial separation on an LH-20 column, Si-flash column chromatography and reverse phase HPLC. Toxins were further identified by comparing their FABMS, ${ }^{1} \mathrm{H}$ and ${ }^{1} \mathrm{H}-{ }^{1} \mathrm{H}$ COSY NMR spectra with the authentic microcystin-LR. Several other microcystin-like compounds were also found in the cultured strains and their structures are being determined. (C) 1998 Elsevier Science Ltd. All rights reserved

Keywords: Cyanobacteria, Microcystis aeruginosa, Hepatotoxin, Microcystins

\section{INTRODUCTION}

Microcystis has been known to be the major genus among the cyanobacteria to cause blooms in fresh waters (Carmichael, 1992). Most species belonging to this genus have been reported to produce a family of over 50 hepatotoxic cyclic peptides which are termed microcystins (MCYST). Cyclo (-D-Ala-X-D-Me-iso-Asp-Z-Adda-D-iso-GluMdha-) was developed in the literature to describe their cyclic peptide structure, where Adda represented $(2 S, 3 S, 8 S, 9 S)$-3-amino-9-methoxy-2,6,8-trimethyl-10-phenyldeca4,6-dienoic acid, a special structural feature responsible for their toxicity (Saito et al., 1994), MeAsp represented the D-erythro- $\beta$-methylaspartic acid, and Mdha, $N$-methyldehydroalanine (Carmichael, 1992). X and Z in the structure denote the variable L-form amino acids at the 2 nd and 4th position, respectively, that were known to include arginine, leucine, phenylalanine, tryptophan, ..., etc. to form the various cyclic heptapeptides (Fig. 1).

* Author to whom correspondence should be addressed. 


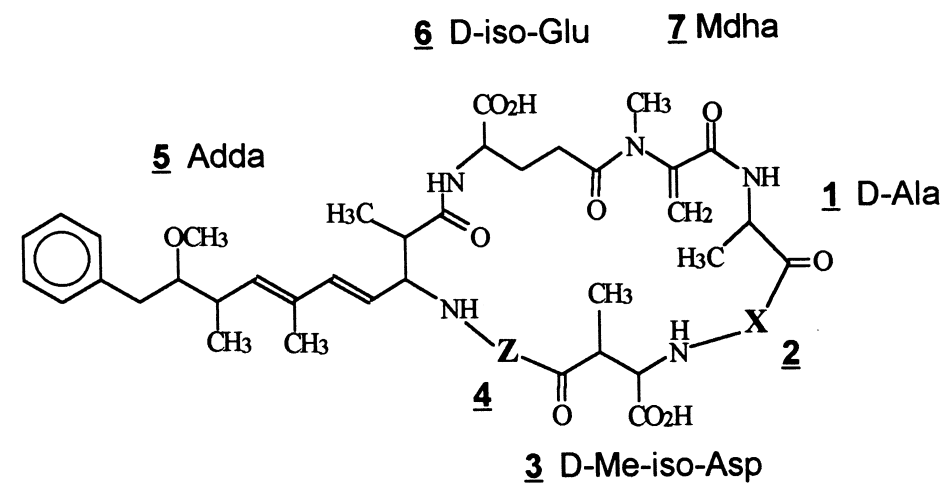

$\begin{array}{lcc} & \text { X } & \text { Z } \\ \text { MCYST-LR } & \text { L-Leu } & \text { L-Arg } \\ \text { MCYST-RR } & \text { L-Arg } & \text { L-Arg } \\ \text { MCYST-RA } & \text { L-Arg } & \text { L-Ala }\end{array}$

Fig. 1. Structures of microcystins identified in this report.

Like many other areas in the world, Microcystis blooms frequently occur in the eutrophic waters of Taiwan, especially in the aquaculture ponds for eel, tilapia and carp. Toxicities and toxins of these Microcystis are of interest due to their threat to humans and animals. There are also reports describing a possible link of human liver disease due to trace microcystins in drinking waters from reservoirs with Microcystis blooms (Falconer et al., 1983; Matsushima et al., 1992; Carmichael, 1994). In Taiwan a relatively comprehensive survey for toxic Microcystis and their toxins was carried out during the past four years.

\section{MATERIALS AND METHODS}

Cyanobacterial cultures

Eight strains of Microcystis aeruginosa Kützing and one Coelosphaerium kuetzingianum Naegeli strain were isolated from fresh water ponds and reservoirs at various locations in Taiwan. These species were collected from the water blooms and then cloned for laboratory cultures (Table 1). They were identified according to the species described in the Plankton Algae of Reservoirs in Taiwan (Moriwaka and Chyi, 1996) and in Mizuno (1980). All clones were cultured in modified Fitzgerald media (Hughes et al., 1958) at $23 \pm 1^{\circ} \mathrm{C}$ and illuminated with fluorescent light of $26.4 \mu \mathrm{mol}$ quanta $/ \mathrm{m}^{2} / \mathrm{s}$ for $12 \mathrm{~h}$ a day. Cyanobacterial cells were collected in their late exponential phase of growth and concentrated by continuous centrifugation, followed by lyophilization and storage. A 1.2 ton mass culture of $M$. TN-2 was carried out for toxin preparation.

Mouse assay

Dried cell mass $(150 \mathrm{mg})$ of each strain of cultured Microcystis and Coelosphaerium was vortexed three times with $10 \mathrm{ml} \mathrm{MeOH}$ and the combined $\mathrm{MeOH}$ extract was dried in vacuum. Dried extract from each cyanobacterial strain was redissolved in $1 \mathrm{ml}$ saline solution for mouse toxicity assay using three mice for each dose level. Mice of $20 \mathrm{~g}$, male, ICR strain, were injected intraperitoneally with the bacterial extracts and they were observed for at least $4 \mathrm{~h}$ for the lethal result (Aune and Berg, 1986). A toxicity threshold dosage was defined in this experiment to show the relative toxicity among strains. The toxicity threshold dose, expressed as the dry weight of bacterial mass per $\mathrm{kg}$ of mouse, is the least quantity of extract that kills all the triplicates of the mice. Six dose levels of the extract equivalent to $1 / 32,1 / 8,1 / 2,2,8$, and $32 \mathrm{mg}$ dried cell mass of each 
Table 1. Collection date and site of Microcystis aeruginosa and Coelosphaerium kuetzingianum cultured in this experiment and their threshold dosage in the mouse toxicity assay

\begin{tabular}{|c|c|c|c|}
\hline Cyanobacterial strain & Collection date & Sampling site & $\begin{array}{l}\text { Threshold dosage (mg dry } \\
\text { bacteria/kg mouse) }\end{array}$ \\
\hline \multicolumn{4}{|c|}{ Microcystis aeruginosa } \\
\hline M. TY-1 & Sep. 1992 & Gongshi, Tauryuan & 25 \\
\hline M. TY $-2^{\mathrm{a}}$ & ? 1992 & ? Tauryuan & 100 \\
\hline M. CY-1 & Aug. 1993 & Dongshyr, Chiayi & 100 \\
\hline M. TN-1 & Aug. 1992 & Dahliao, Tainan & $-\mathrm{b}$ \\
\hline M. TN-2 & Jul. 1993 & Duujia, Tainan & 25 \\
\hline M. TN-3 & Jul. 1993 & Duujia, Tainan & 100 \\
\hline M. TN-4 & Sep. 1994 & Duujia, Tainan & 25 \\
\hline M. KS-1 & Aug. 1989 & Cherngching Lake & $-{ }^{\mathrm{b}}$ \\
\hline \multicolumn{4}{|c|}{ Coelosphaerium kuetzingianum } \\
\hline C. TN-1 & Aug. 1992 & Dahliao, Tainan & $-{ }^{b}$ \\
\hline
\end{tabular}

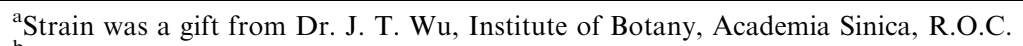

${ }^{\mathrm{b}}$ Classified as nontoxic due to the threshold dose higher than $1.6 \mathrm{~g}$ dry bacteria $/ \mathrm{kg}$ mouse.

strain were tested for the toxicity threshold. Dead mice were dissected to observe the swollen blood-engorged liver that is generally recognized as an indicator of microcystin poisoning (Azevedo et al., 1994).

A field-collected sample, consists of $M$. aeruginosa cells from the eel pond scum, was studied in a similar way to compare its toxicity with the cultured strains. One gram of dried cells was extracted three times with $30 \mathrm{ml} \mathrm{MeOH}$. The dried extract was then diluted with various amounts of saline solution to give 5 different doses equivalent to $1,5,10,50$, and $100 \mathrm{mg}$ of dried cells per $\mathrm{ml}$. Six mice were used for each dose level as duplications.

Sample preparation and high performance liquid chromatography

Lyophilized cells $(50 \mathrm{mg})$ of each cyanobacterial strain were extracted 3 times with $3 \mathrm{ml} \mathrm{MeOH}$ and then centrifuged at $1500 \mathrm{~g}$ for $10 \mathrm{~min}$ to remove cell debris. Supernatant was vacuum-dried and redissolved in trace amount of ethylacetate: isopropanol $(4: 3, \mathrm{v} / \mathrm{v})$ solution for solid phase extraction. Accubond silica SPE columns ( $6 \mathrm{ml}, 0.5 \mathrm{~g}$ silica gel) (Fison, England) were preconditioned with $6 \mathrm{ml}$ of the same solution and then washed with $10 \mathrm{ml}$ of the solution after the load of samples. The toxin fraction was eluted with $4 \mathrm{ml}$ of ethylacetate: isopropanol: $\mathrm{H}_{2} \mathrm{O}(4: 2.5: 1.5, \mathrm{v} / \mathrm{v})$ through the column and evaporated to remove the solvent. The eluent volume had been determined through a preliminary experiment using the samples of toxin standards (MCYST-LR and MCYST-RR) mixed with crude extracts. Toxin fractions of each bacterial sample were dried and redissolved in $250 \mu \mathrm{l} \mathrm{MeOH}$, using $2 \mu \mathrm{l}$ for each HPLC analysis. The high performance liquid chromatography (HPLC) used a $4.6 \times 250 \mathrm{~mm}$ Cosmosil 5C18-AR column (Nacalai Tesque, Japan) and an isocratic solution of $0.05 \%$ aq. trifluoroacetate: $\mathrm{MeOH}(48: 52, \mathrm{v} / \mathrm{v})$ as mobile phase, flow rate $1 \mathrm{ml} / \mathrm{min}$.

Toxin extraction and isolation

Dried cells ( $24 \mathrm{~g}$ ) from $M$. aeruginosa strain $M$. TN-2 were extracted three times with $400 \mathrm{ml} \mathrm{MeOH}$ for $30 \mathrm{~min}$ each. The $\mathrm{MeOH}$ extract was adjusted to $85 \%$ in aqueous solution for hexane partition. The aqueous layer was then vacuum-evaporated to dryness $(1.8 \mathrm{~g})$ and redissolved in $90 \mathrm{ml} \mathrm{MeOH}$ for nine different batches of chromatographic separations.

The first separation step was carried out using gel filtration chromatography on a Sepadex LH-20 (Pharmacia Biotech. Sweden) column $(3 \times 55 \mathrm{~cm})$ for each $10 \mathrm{ml}$ sample solution. A flow of $13 \mathrm{ml} / \mathrm{min}$ of $\mathrm{MeOH}$ was used to elute the toxin fractions. Each fraction was compared with an authentic sample of microcystin-LR (Sigma, U.S.A.) by thin layer chromatography (TLC) using plates of Silica gel 60, PF254, $200 \mu \mathrm{m}$ thickness (Merck, U.S.A.) and a solution of ethylacetate: isopropanol: $\mathrm{H}_{2} \mathrm{O}(4: 2.5: 2, \mathrm{v} / \mathrm{v} / \mathrm{v})$ for development. Vanillin-sulfuric acid charring to form dark blue spots in addition to UV absorption was used to detect the toxic components. Subsequently the toxin fractions were combined and chromatographed on a $3 \mathrm{~cm}$ i.d. flash column (42.5 g, Baker's silica gel for flash column, U.S.A.) using the same solution in TLC as the eluent, flow rate $36 \mathrm{ml} / \mathrm{min}$. The toxin fractions were combined into two major portions based on the result of TLC separation and vanillin-sulfuric acid charring. Microcystin (MCYST)-LR, -RR, and -RA were further purified from the above toxin fractions by repetitive HPLC separations on an Econosil C18 5U analytical column (Alltech, U.S.A.) using 0.1 M ammonium acetate: methanol (43:57, v/v) as mobile phase, flow rate $1 \mathrm{ml} / \mathrm{min}$. Purified toxins were vacuum-dried and stored in $-20^{\circ} \mathrm{C}$ freezer for further chemical structure analysis. 
Structure identification

UV spectra of isolated microcystins were measured on a U-2000 Spectrophotometer (Hitachi, Japan). Molecular weight of each toxin was determined by FABMS on a Jeol SX102A Spectrometer (Jeol, Japan) using glycerol $(m / z=92)$ as the matrix. Structures of the isolated toxins were elucidated by comparing their ${ }^{1} \mathrm{H}$ nuclear magnetic resonance (NMR) spectra with that of authentic MCYST-LR (Sigma, U.S.A.). Identification of MCYST-LR was also supported by comparing its chromatographic characteristics with those of authentic. All the NMR spectra of MCYST analogues were measured on a Bruker AM-400 FT-NMR Spectrometer (Bruker, Germany), using the solvent $\mathrm{MeOH}-\mathrm{d}_{4}$ (peaked at $\delta 4.9$ ) for chemical shift calibration.

\section{Amino acid analysis}

Each toxin component was hydrolyzed by gas-phase hydrolysis in $500 \mu \mathrm{l}$ of $7 \mathrm{M} \mathrm{HCl}$ and $10 \%$ trifluoroacetic acid containing $0.1 \%$ phenol at $158^{\circ} \mathrm{C}$ for $30 \mathrm{~min}$ (Chang and Liu, 1988). Released amino acids were then reacted with 4-dimethylaminoazobenzene-4'-sulfonyl chloride (DABS-Cl) to form color derivatives prior to the HPLC analysis. HPLC separation used an Alltima C18 Column $(4.6 \times 250 \mathrm{~mm}$, Alltech, U.S.A.) with a gradient elution of $15 \%$ to $40 \%$ of acetonitrile in $35 \mathrm{mM}$ sodium acetate solution containing $4 \% \mathrm{~N}, \mathrm{~N}$-dimethylformamide for the first $20 \mathrm{~min}$, then a gradient of $40 \%$ to $70 \%$ of acetonitrile for the following $12 \mathrm{~min}$ and an isocratic wash of $70 \%$ acetonitrile for the last $2 \mathrm{~min}$, at a flow rate of $1 \mathrm{ml} / \mathrm{min}$ for the entire elution period. DABS-derivatives of amino acids were detected by $436 \mathrm{~nm}$ absorption.

\section{RESULTS}

Eight $M$. aeruginosa strains and one $C$. kuetzingianum strain were tested for their mouse toxicities by injecting intraperitoneally various amounts of their $\mathrm{MeOH}$ extracts. The toxicity threshold dosages were defined here as the minimal dose of the $\mathrm{MeOH}$ extract of dried cells to kill all the triplicates of injected mice within four hours. The threshold doses of each strain of cyanobacteria were presented in Table 1 to show the relative toxicity among these cultured strains. Among the cyanobacteria, $M$. TY-1 was the most toxic because a dose level $(6.25 \mathrm{mg}$ dry cell mass $/ \mathrm{kg}$ mouse) lower than its threshold dosage $(25 \mathrm{mg})$ showed lethal toxicity to two thirds of the tested mice. $M$. TN-2 and $M$. TN-4 strains of $M$. aeruginosa having the same threshold toxicity as $M$. TY-1 but without any toxicity at a lower dose level were ranked the second. $M$. TN-1 and $M$. KS-1 of $M$. aeruginosa and $C$. TN-1 of $C$. kuetzingianum were classified as nontoxic because none of the injected mice died even at a dose level of $1.6 \mathrm{~g}$ dry cell mass/ $\mathrm{kg}$ mouse, the highest dose level in this experiment. Six of eight $M$. aeruginosa strains were found to be toxic but variable in their toxicity. All dead mice from injection of Microcystis extracts showed swollen blood-engorged livers which comprised about $10 \%$ of the body weight (compared to $6 \%$ found in the control mice). In addition to the cultured strains of $M$. aeruginosa, cells of the same species from a natural bloom in an eel pond were also extracted for mouse toxicity assay. All five dose levels except the extract of $1 \mathrm{mg}$ dried bacteria killed mice. The toxicity threshold dose for this natural population of Microcystis was estimated to range between $50-250 \mathrm{mg}$ dry cell mass $/ \mathrm{kg}$ mouse and thus less toxic than the cultured strains. It was also noted that at least $40 \mathrm{~min}$, a minimal reaction time, was required to observe the death response of mouse after an intraperitoneal (i.p.) administration of a lethal dose of the cyanobacterial extract.

Toxin profiles of cultured Microcystis and Coelosphaerium strains were studied by a reversed phase HPLC. HPLC analysis showed that all six toxic Microcystis strains contain MCYST-LR and MCYST-RR. Identification of MCYST-LR was confirmed by comparing its NMR spectrum with that of an authentic standard and by co-injecting the authentic sample with the cyanobacterial extract in the HPLC analysis. MCYSTRR was also identified by comparing its NMR spectrum with that of MCYST-LR. Content of MCYST-LR and MCYST-RR in cultured strains of Microcystis and Coelosphaerium are listed in Table 2. All the toxic strains studied in this experiment 
Table 2. Contents of microcystins, MCYST-LR and MCYST-RR in the toxic strains of Microcystis aeruginosa. Figures of the content were calculated from the linear relationship $\left(y=500.55 x-4845.40, r^{2}=0.9952\right.$ for MCYST-LR; $y=828.01 x-23945.01, r^{2}=0.9951$ for MCYST-RR) of the peak area $(y)$ and the injected authentics $(x$, in $\mathrm{ng})$ obtained by an HPLC analysis using a Cosmosil 5C18-AR $(4.6 \times 250 \mathrm{~mm})$ column and $\mathrm{MeOH}$ : $0.05 \%$ aq. TFA $(52: 48)$ as mobile phase, flow rate $1 \mathrm{ml} / \mathrm{min}$

\begin{tabular}{lcc}
\hline Strain & $\begin{array}{c}\text { microcystin-LR } \\
(\mu \mathrm{g} / \mathrm{mg} \text { dry bacteria })\end{array}$ \\
\hline$M$. TY-1 & 10.06 & 0.08 \\
$M$. TY-2 & 0.54 & 1.58 \\
$M$. CY-1 & 0.11 & 0.18 \\
$M$. TN-2 & 0.33 & 0.72 \\
$M$. TN-3 & 0.23 & 0.63 \\
$M$. TN-4 & 1.49 & 2.21 \\
\hline
\end{tabular}

contained both MCYST-LR and -RR, although they varied in their relative contents. Generally the toxic strains contained about 1.5-2.9 times more MCYST-RR than MCYST-LR, except $M$. TY-1 strain which contained mostly MCYST-LR at higher than $10 \mu \mathrm{g}$ per mg dry cell mass, much higher than the average $0.54 \mu \mathrm{g}$ in the rest of the toxic Microcystis spp. studied.

Microcystins-LR, -RR, and -RA, reported in this paper co-eluted in a very close fraction by the gel permeation chromatographic separation. They were the major microcystins in $M$. TN-2 cells and appeared in the fractions shown by the first and second peaks if the separation was monitored with $\mathrm{UV}_{254}$ absorption. $R_{\mathrm{f}}$ values of MCYST-LR, MCYST-RR, and MCYST-RA shown on the silica gel plate of TLC separation were $0.28,0.16$, and 0.32 respectively. A TLC analytical system using silica gel 60 plates with ethylacetate: isopropanol: $\mathrm{H}_{2} \mathrm{O}(4: 2.5: 2, \mathrm{v} / \mathrm{v} / \mathrm{v})$ was always used as a performance check for preparative separations. Further separation by the silica gel flash column chromatography yielded two toxin fractions, one contained MCYST-LR and MCYST-RA and another contained MCYST-RR. From these two fractions toxin components were further purified by a reversed phase high performance liquid chromatography. From $24 \mathrm{~g}$ dried cells of $M$. TN-2, $2.0 \mathrm{mg}$ of MCYST-LR, $0.8 \mathrm{mg}$ of MCYST-RR, and $1.4 \mathrm{mg}$ of MCYST-RA were obtained. The recovery of MCYST-RR was apparently much lower than that of MCYST-LR during preparative separation of microcystins. Toxin analysis of the natural Microcystis population showed less MCYST-LR and -RR but with several other different microcystins and their derivatives in trace amounts. These microcystins are currently under investigation.

All three toxin components were collected until a sufficient amount was obtained for NMR 1D and 2D spectroscopic studies. Data of the ${ }^{1} \mathrm{H}-\mathrm{NMR}$ and their assignments of these three toxins were compared with those of MCYST-LR given by Namikoshi et al. (1990). It was found that proton chemical shifts of MCYST-LR isolated in this research coincided very well with the data given by Namikoshi et al. except some irresolvable coupling constants. Two dimensional NMR of ${ }^{1} \mathrm{H}-{ }^{1} \mathrm{H}$ homoCOSY gave further evidences showing the correlation of protons within each amino acid of these cyclic heptapeptides. FABMS spectrometry provided its molecular ions $(\mathrm{M}+\mathrm{H})^{+}$at 995 for MCYST-LR, 1038 for MCYST-RR, and 953 for MCYST-RA that also matched to the postulated toxin compositions which were further confirmed by the amino acid analysis. Amino acid composition of these three toxins was analyzed by an HPLC separation on the DABS-derivatives of their acid hydrolysate. D-iso-Glu, D-Ala, and L-Arg of the tox- 


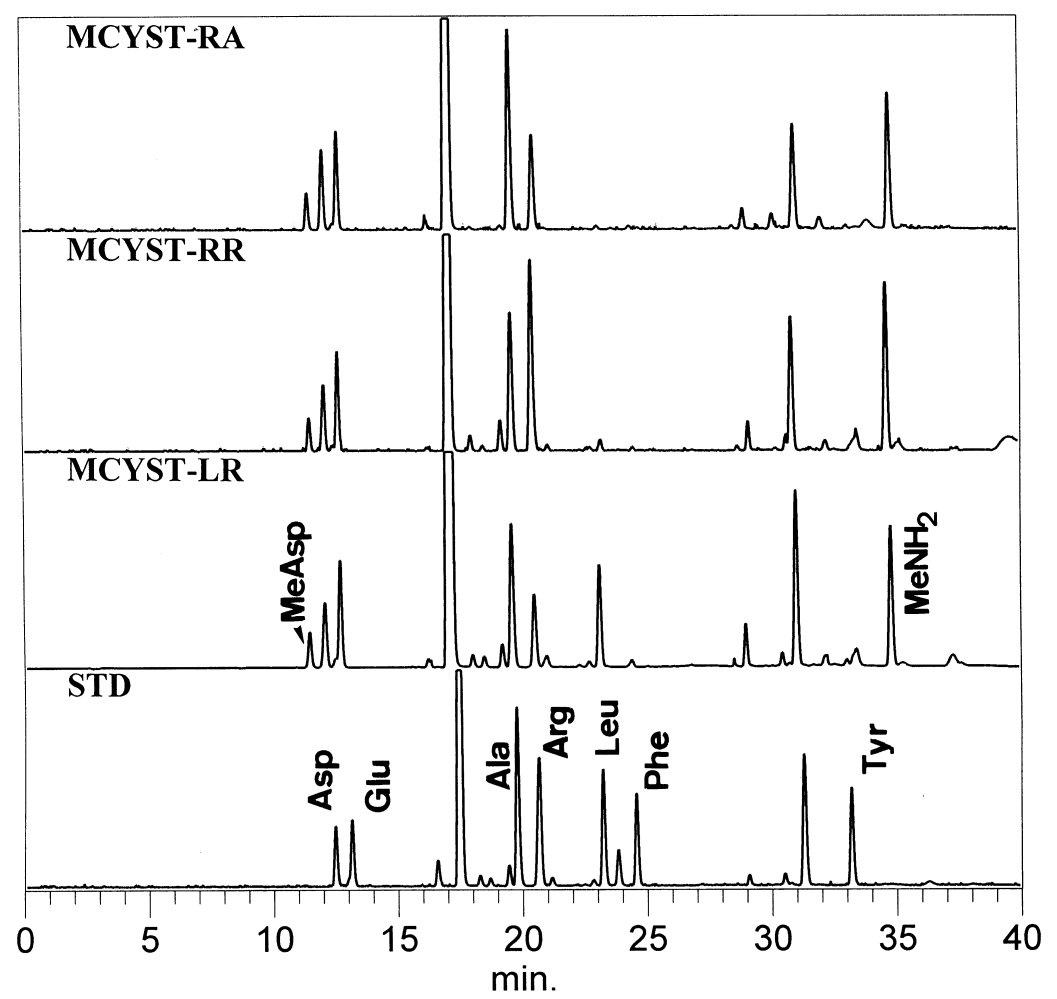

Fig. 2. HPLC analysis of amino acid composition of microcystin (MCYST)-LR, -RR, and -RA using a column of Alltima C18 $(4.6 \times 250 \mathrm{~mm})$ eluted with a gradient solution of $15 \%$ to $70 \%$ of acetonitrile in $35 \mathrm{mM}$ sodium acetate solution containing $4 \% N, N$-dimethylformamide. Samples were prepared from a dabsyl derivatization of the microcystin acid hydrolysates.

ins gave separated peaks which were identified by the authentic amino acid individually (Fig. 2). Amino acid isomers can not be distinguished by the method reported here. DMe-iso-Asp derivatives from the toxins gave two separated peaks of Asp and MeAsp adducts with their peak areas in a ratio about 2:1 (Fig. 2). A common peak of methylamine derivative shown in all three toxin chromatograms (Fig. 2) was generated by Mdha of microcystins. Peak derived from L-Arg of MCYST-RR showed peak areas in twofold of that of MCYST-LR and MCYST-RA. MCYST-RA also gave a higher alanine peak than MCYST-LR or MCYST-RR in the amino acid separation. An extra peak which was only observed in MCYST-LR chromatogram was identified as DABSderivative of L-leucine by comparing the retention time of the authentic (Fig. 2). MCYST-RA, the least polar component among the toxins identified in this research, was postulated a new toxin, even its molecular weight was found to be the same as the reported MCYST-AR (Namikoshi et al., 1992). The location of L-arginine (at the 2nd position) and L-alanine (at the 4th position) in the cyclopeptidic MCYST-RA was determined by comparing their chemical shifts on NMR spectrum with those of MCYST-LR and MCYST-RR. The same proton chemical shifts of $[\mathrm{Arg}]_{4}$ of MCYST-LR and MCYST-RR were not found, instead the proton signals of $[\mathrm{Arg}]_{2}$ as assigned for MCYST-RR were observed on MCYST-RA spectrum. 


\section{DISCUSSION}

While calculating the data in Table 1, the toxicity threshold dose, and Table 2, the contents of MCYST-LR and -RR in cyanobacteria, we came to an assumption that the specific toxicity of MCYST-LR and MCYST-RR in a form of $\mathrm{LD}_{100}$ (per $\mathrm{kg}$ of mouse) ranges, respectively, 252-8 $\mu \mathrm{g}$ and $221-2 \mu \mathrm{g}$. Comparing with the $\mathrm{LD}_{50}(50 \mu \mathrm{g} / \mathrm{kg}$ mouse for MCYST-LR and $600 \mu \mathrm{g} / \mathrm{kg}$ mouse for MCYST-RR) given by Rinehart et al. (1994), our result suggested that there were other toxins beside the identified MCYST-LR and RR in the toxic Microcystis strains. From one of our toxic strains, M. TN-2, cultured cells gave a bundle of microcystin analogues in the preliminary screen and their derivatives to be resolved. In this report we demonstrated a new toxin, MCYST-RA, in addition to the popular ones, MCYST-LR and -RR from $M$. TN-2. However there are still many other microcystins in $M$. TN-2 that remain to be determined. MCYST-LR and MCYST-RR were not only in M. TN-2 but also in all the toxic Microcystis strains in this study. This result follows the conclusion made by Rinehart et al. (1994) that MCYST-LR and -RR were the most common components among the known microcystins in the studied Microcystis strains.

Mouse assay of the toxic Microcystis strain showed the toxicity close to that $\left(\mathrm{LD}_{100}=31 \mathrm{mg} / \mathrm{kg}\right.$ mouse by i.p. injection) obtained by Azevedo et al. (1994). Our mouse assay also gave a result to show that a minimum of 40 min was needed to observe the lethal effect on mouse after an i.p. injection of cyanobacterial extract at a dose higher than the threshold dosage. It has been reported that the time required for maximal toxin accumulation in liver varied from 1 min (Brooks and Codd, 1987) to $60 \mathrm{~min}$ (Robinson et al., 1989) depending on the amount of MCYST-LR administered. Histological data of Hermansky et al. (1993) also showed that the most striking ultrastructural changes within the hepatic parenchyma appeared at $45 \mathrm{~min}$ after the i.p. injection of MCYST-LR. These studies demonstrated that the liver damage caused by toxin accumulation in hepatocytes is a time-consuming process. Moreover, the transportation of injected microcystins through hepatocyte membrane may require longer time. A newly-found inhibition activity of microcystins on the protein phosphatase 1 and $2 \mathrm{~A}$ (Eriksson et al., 1990); Nishiwaki-Matsushima et al., 1992) was an assumed mechanism by which microcystins exert their hepatotoxicity. Due to the enzyme inhibitions, hepatocytes shrink and cause liver damage, followed by internal hemorrhage (Runnegar and Falconer, 1986). The death of a $20 \mathrm{~g}$ mouse due to the hemorrhage shock takes more than $40 \mathrm{~min}$ in this case. It is expected that the time needed to show the death of experiment animals will vary with the different species, and different weights and ages of the same species. There are also other toxicological mechanisms on different group of animals. Recently Bury et al. (1996) and Zambrano and Canelo (1996) reported that microcystins exert their lethal toxicity on fresh water fish by disrupting the ion homeostasis of the internal medium via blockage of gill function.

According to Carmichael (1994), there are 47 microcystins reported to have a common feature of a cyclic heptapeptide structure (Fig. 1). Among these amino acid residues, the 2 nd and 4th L-form amino acids are usually substituted with different amino acids to form the microcystin variants. Rinehart et al. (1994) have summarized all these analogues and made a list showing the structural differences. It was found that only two microcystins contained L-alanine at the 4th position while almost $80 \%$ of the known microcystins had L-arginine at this position. The postulated MCYST-RA in this paper having an alanine at the 4th amino acid position is a new and distinctive compound. 
Blooms of Microcystis in the lakes and reservoirs have been known to cause poisoning for livestock and wildlife (Gorham and Carmichael, 1988). Recent studies showed that toxins of Microcystis may also cause the hepatotoxicosis, gastroenteritis, and allergic reactions in human (Turner et al., 1990; Soong et al., 1992) and the adverse effects on aquatic lives (Codd, 1984; Philips et al., 1985). Microcystins and their toxicology have attracted the worldwide attentions for more than twenty years. In Taiwan Microcystis blooms are very common in aquaculture ponds of both fresh and brackish water. Some blooms may contain microcystins and remain blooming for the year round. However, so far we have never observed any serious adverse effects of Microcystis bloom on aquatic lives or aquaculture product consumers. Further toxin research and ecological or toxicological studies are still needed to better understand chronic effects of microcystins on human health and the formation and decay of microcystins in the environment.

Acknowledgements - Part of this work was grant funded by National Science Council (Grant No.: NSC862113-M002-014), Taiwan, Republic of China. Portions of this manuscript were preliminarily presented during the 7th International Conference on Toxic Phytoplankton, Sendai, Japan, 1995.

\section{REFERENCES}

Aune, T. and Berg, K. (1986) Use of freshly prepared rat hepatocytes to study toxicity of blooms of the bluegreen algae Microcystis aeruginosa and Oscillatoria agardhii. J. Toxicol. Environ. Health 19, 325-336.

Azevedo, S. M. F. O., Evans, W. R., Carmichael, W. W. and Namikoshi, M. (1994) First report of microcystins from a Brazilian isolate of the cyanobacterium Microcystis aeruginosa. J. Appl. Phycol. 6, 261-265.

Brooks, W. P. and Codd, G. A. (1987) Distribution of Microcystis aeruginosa peptide toxin and interactions with hepatic microsomes in mice. Pharmacol. Toxicol. 60, 187-191.

Bury, N. R., Flik, G., Eddy, F. B. and Codd, G. A. (1996) The effects of cyanobacteria and the cyanobacterial toxin microcystin-LR on $\mathrm{Ca}^{2+}$ transport and $\mathrm{Na}^{+} / \mathrm{K}^{+}$-ATPase in tilapia gills. J. Exp. Biol. 199, 1319-1326.

Carmichael, W. W. (1992) Cyanobacteria secondary metabolites - the cyanotoxins. J. Appl. Bact. 72, 445459.

Carmichael, W. W. (1994) The Toxins of cyanobacteria. Sci. Am. 270, 64-72.

Chang, C. S. and Liu, C. S. (1988) A picomole-level amino acid analysis by means of gas-phase hydrolysis and DABS-Cl/HPLC method. J. Chinese Biochem. Soc. 17, 12-19.

Codd, G. A. (1984) Toxins of freshwater cyanobacteria. Microbiol. Sci. 1, 48-52.

Eriksson, J. E., Toivola, D., Meriluoto, J. A. O., Karaki, H., Han, Y.-G. and Hartshorne, D. (1990) Hepatocyte deformation induced by cyanobacterial toxins reflects inhibition of protein phosphatases. Biochem. Biophys. Res. Commun. 173, 1347-1353.

Falconer, I. R., Beresford, A. M. and Runnegar, M. T. C. (1983) Evidence of liver damage by toxin from a bloom of the blue-green alga, Microcystis aeruginosa. Med. J. Aust. 1, 511-514.

Gorham, P. R. and Carmichael, W. W. (1988) Hazards of freshwater blue-green algae (cyanobacteria). In Algae and Human Affairs, eds. C. A. Lembi, J. R. Waaland, pp. 403-431. Cambridge University Press, Cambridge.

Hermansky, S. J., Markin, R. S., Flower, E. H. and Stohs, S. J. (1993) Hepatic ultrastructural changes induced by the toxin microcystin-LR (MCLR) in mice. J. Environ. Pathol. Toxicol. and Oncol. 12, $101-106$.

Hughes, E. O., Gorham, P. R. and Zehnder, A. (1958) Toxicity of a unialgal culture of Microcystis aeruginosa. Can. J. Microbiol. 4, 225-236.

Matsushima, R. N., Ohta, T., Nishiwaki, S., Suganuma, M., Kohyama, K., Ishikawa, T., Carmichael, W. W. and Fujiki, H. (1992) Liver tumor promotion by the cyanobacterial cyclic peptide toxin microcystin-LR. $J$. Cancer Res. Clin. Oncol. 116, 609-614.

Mizuno, T. (1980) Illustrations of the Freshwater Plankton of Japan. Hoikusha Publishing, Osaka.

Moriwaka, M. and Chyi, J. (1996) Plankton Algae of Reservoirs in Taiwan. Natl. Inst. Environ. Anal., EPA, Taipei, R.O.C.

Namikoshi, M., Rinehart, K. L., Sakai, R., Sivonen, K. and Carmichael, W. W. (1990) Structures of three new cyclic heptapeptide hepatotoxins produced by the cyanobacterium (blue-green alga) Nostoc SP. strain 152. J. Org. Chem. 55, 6135-6139.

Namikoshi, M., Rinehart, K. L., Sakai, R., Stotts, R., Dahlem, A. M., Beasley, V. R., Carmichael, W. W. and Evans, W. R. (1992) Identification of 12 hepatotoxins from a Homer Lake bloom of the cyanobacteria Microcystis aeruginosa, Microcystis viridis, and Microcystis wesenbergii: nine new microcystins. J. Org. Chem. 57, 866-872. 
Nishiwaki-Matsushima, R., Ohta, T., Nishiwaki, S., Suganuma, M., Kohyama, K., Ishikawa, T., Carmichael, W. W. and Fujiki, H. (1992) Liver tumor promotion by the cyanobacterial cyclic peptide toxin microcystinLR. J. Cancer Res. Clin. Oncol. 118, 420-424.

Philips, M. J., Roberts, R. J. and Stewart, J. A. (1985) The toxicity of the cyanobacterium Microcystis aeruginosa to rainbow trout, Salmo gairneri Richardson. J. Fish Dis. 8, 339-343.

Rinehart, K. L., Namikoshi, M. and Choi, B. W. (1994) Structure and biosynthesis of toxins from blue-green algae (cyanobacteria). J. Appl. Phycol. 6, 159-176.

Robinson, N. A., Miura, G. A., Matson, C. F., Dinterman, R. E. and Pace, J. G. (1989) Characterization of chemically tritiated microcystin-LR and its distribution in mice. Toxicon 27, 1035-1042.

Runnegar, M. T. C. and Falconer, I. R. (1986) Effect of toxin from tha cyanobacterium Microcystis aeruginosa on ultrastructural morphology and actin polymerization in isolated hepatocytes. Toxicon 24, 109-115.

Saito, S., Nakano, Y., Kushida, K., Shiral, M., Harada, K.-I. and Nakano, M. (1994) Cross-reactivity and neutralizing ability of monoclonal antibodies against microcystins. Microbiol. Immunol. 38, 389-392.

Soong, F. S., Maynard, E., Hollinrake, K. and Luke, C. (1992) Illness associated with blue-green algae. Med. J. Aust. 156, 67.

Turner, P. C., Gammie, A. J., Hollinarake, K. and Codd, G. A. (1990) Pneumonia associated with contact with cyanobacteria. Br. Med. J. 300, 1440-1441.

Zambrano, F. and Canelo, E. (1996) Effects of microcystin-LR on the partial reactions of the $\mathrm{Na}^{+}-\mathrm{K}^{+}$pump of the gill of carp (Cyprinus carpio Linneo). Toxicon 34, 451-458. 